\title{
MANAGEMENT OF DIAPHYSEAL FRACTURES OF TIBIA IN ADULTS TREATED EITHER WITH CAST OR INTRAMEDULLARY NAILING WITH SPECIAL REFERENCE TO ENDERS NAIL
}

\author{
${ }^{1}$ Assistant Professor, Department of Orthopaedics, JSSH, Mysore. \\ ${ }^{2}$ Senior Resident, Department of Orthopaedics, JSSH, Mysore. \\ ${ }_{3}^{3}$ Assistant Professor, Department of Orthopaedics, JSSH, Mysore. \\ ${ }^{4}$ Senior Resident, Department of Orthopaedics, JSSH, Mysore. \\ ${ }_{5}^{5}$ Assistant Professor, Department of Orthopaedics, JSSH, Mysore. \\ 6Junior Resident, Department of Orthopaedics, JSSH, Mysore.
}

Ravi Kiran H. G1, Supreeth Nekkanti², Adarsh T33, Pramod T4, Gurumurthy B5, Ishani Patel ${ }^{6}$

\section{ABSTRACT}

Fractures of the tibial shaft are important for the reason that they are common and controversial. The exposed anatomical location of the tibia makes it vulnerable to the direct blow and high energy trauma as a result of motor vehicle accidents, thus resulting in comminuted fractures, which are frequently open with significant loss of skin and soft tissues. Because of the high prevalence of complications associated with these fractures, management often is difficult and the optimum method of treatment remains a subject of controversy.

\section{MATERIALS AND METHODS}

We aim to study all the cases with diaphyseal fractures of tibia in adults. We also wanted to study clinically and radiologically the incidence, causes, types and various types of management of diaphyseal fractures of tibia with special emphasis on Ender nailing. Finally, we compared our results of cases managed by different treatment methods.

\section{CONCLUSION}

Out of the various treatment modalities, in our experience surgical management of diaphyseal tibia fractures has better functional outcomes compared to conservative management. The incidence of complications like knee and ankle stiffness and malunion are much lesser in surgical management compared to the patients managed conservatively. Out of the two surgical methods, patients operated with IMIL nails had better function and lesser complications.

\section{KEYWORDS}

Diaphyseal Fracture Tibia; Enders Nail; Comparative Study; Conservative Management.

HOW TO CITE THIS ARTICLE: Kiran RHG, Nekkanti S, Adarsh T, et al. Management of diaphyseal fractures of tibia in adults treated either with cast or intramedullary nailing with special reference to enders nail. J. Evolution Med. Dent. Sci. 2016;5(60):4225-4233, DOI: $10.14260 /$ jemds/2016/964

\section{INTRODUCTION}

Fractures of the tibial shaft are important for the reason that they are common and controversial.[1] The exposed anatomical location of the tibia makes it vulnerable to the direct blow and high energy trauma as a result of motor vehicle accidents, thus resulting in comminuted fractures which are frequently open with significant loss of skin and soft tissues. ${ }^{[2]}$ Because of the high prevalence of complications associated with these fractures, management often is difficult and the optimum method of treatment remains a subject of controversy. [3]

Among the various modalities of treatment such as conservative gentle manipulation and use of short leg or long leg cast, open reduction and internal fixation with plates and screws, intramedullary fixation (Including Ender Pins, intramedullary nails and interlocking intramedullary nails with reaming (or) without Reaming) and External fixation techniques, surgeon should be capable of using all these techniques and must weigh advantages and disadvantages of

Financial or Other, Competing Interest: None.

Submission 24-06-2016, Peer Review 14-07-2016,

Acceptance 20-07-2016, Published 28-07-2016.

Corresponding Author:

Dr. Supreeth Nekkanti,

Senior Resident,

Department of Orthopaedics,

JSSH, Mysore.

E-mail: drsupreethn@gmail.com

DOI: $10.14260 /$ jemds/2016/964 each one and adapt the best possible treatment. [1,2,3,4] The best treatment is determined by a thoughtful analysis of morphology of the fracture, the amount of energy imparted to the extremity, the mechanical characteristics of the bone, the age and general conditions of the patient and most importantly the status of the soft tissues (The skin, muscle associated neurologic and vascular structure of the leg).

Three goals must be met for the successful treatment of fractures of tibia. The prevention of infection, the achievement of bony union and the restoration of function. These goals are interdependent and usually are achieved in the chronological order given.

Immobilization in a plaster cast has been used most commonly in the past, but it does not always maintain the length of the tibia and it leaves the wound relatively inaccessible.[1]

Open reduction and internal fixation with plates and screws has yielded unacceptably high rates of infection. This method may be selected with more severe or local injuries associated displaced intra-articular fractures of knee and ankle.

External fixation considered the treatment of choice by many traumatologists, has the disadvantages of distraction at the fracture site leading to non-union. Apart from it bulky frames and frequent pin tract infections make it an unfavourable choice of implant.[2] 
The intramedullary nailing, locked or unlocked has become an attractive option since image intensifier has made closed intramedullary nailing possible. ${ }^{[3,4]}$ Nail is a load sharing device and is stiff to both axial and torsional forces. Closed nailing involves least disturbance of soft tissue, fracture haematoma and natural process of bone healing as compared to other forms of internal fixation. [4]

Intramedullary nails, such as Lottes and Ender nails used without reaming have been employed successfully in the treatment of open tibial fractures and have been associated with low rates of post-operative infection. They are, however, contraindicated for comminuted fractures, as there tends to be shortening or displacement of such fractures around these small nails. ${ }^{[2]}$

The locking of intramedullary nails to the major proximal and distal fragments decreases the prevalence of malunion of comminuted fractures. Until recently, however, all interlocking intramedullary nailing involved reaming, which destroys the endosteal blood supply. However, the role of this mode of treatment has been limited to considerable extent in modern era. Reamed or unreamed closed interlocking nails have become the mainstay for the treatment of these fractures. Interlocking nails demand modern gizmos, advanced expertise and costly implants. ${ }^{[4]}$

Enders nails being flexible, cheap, affordable simple and biological have been used successfully for treatment of tibial fractures. The technique combines the benefits of both surgical and closed functional methods of treatment. ${ }^{[4]}$

\section{MATERIALS AND METHODS}

This study consisted of 60 cases of diaphyseal fractures of tibia, treated in the Department of Orthopaedics at a tertiary care teaching hospital of a medical school in Mysore between July 2013 and September 2015. Approval for the study was obtained from Institutional Ethical Committee.

Tibial fractures were classified according to GustiloAnderson classification ${ }^{1}$ for open fractures and closed tibial fractures were classified based on the degree of comminution and pattern of fracture. The treatment protocol was planned accordingly.

During this period, patients were treated for diaphyseal fractures of tibia of which 18 patients were treated by Ender nails and 22 patients were treated by reamed interlocking nail under image intensifier. Remaining 20 cases were treated by conservative method only.

All the required data was collected from the patients during their stay in the hospital, during follow-up at regular intervals and from the medical records.

All the patients diagnosed to have diaphyseal fractures of tibia in the age group of 18-60 years including Grade-I (Gustilo-Anderson) compound fractures with small contaminated wound over the fractures.

The excluded patients were, a) Fracture in children less than 18 years, b) Geriatric patients above 60 years, c) Compound fracture Gustilo-Anderson Type II and Type III and d) Cases of upper end and lower end fractures of tibia.

The patients were first attended to in the emergency room. A thorough history was obtained from the patient followed by a detailed examination of the patient's limb was done. The fracture was classified as open or closed and graded accordingly.
Surgical method of treatment was mainly based on the type and fractures and amount of displacement. The patients were taken for surgery at the earliest possible time depending on their medical condition.

\section{Surgical Management}

We have used interlocking nail with reaming of medullary cavity under image intensifier and under portable X-ray control. Total of 22 cases were taken, 18 was in static mode and 4 were in dynamic mode. 5 The length of the nail is calculated by subtracting 3 to $4 \mathrm{cms}$ from measurement taken from the knee joint line to tip of the medial malleolus. ${ }^{6}$ The diameter of the nail is measured roughly by measuring medullary cavity diameter of tibial roentgenogram at the narrowest part. We have used 8 and $9 \mathrm{~mm}$ of nails.

\section{Operative Technique of Ender Nail}

Closed nailing is performed on a regular operating room table using general or regional anaesthesia. A wooden or plastic is substituted for the foot portion of the operating room table. The procedure is done under pneumatic tourniquet control with biplanar image intensification. With the knee flexed over a sterile bolster, $5 \mathrm{cms}$ oblique incisions are made down to bone in the mid-coronal plane over the subcutaneous medial and lateral condyles of the tibia. The portal of entry into bone on the medial side is approximately $2.5 \mathrm{cms}$ below the medial joint line. ${ }^{7}$ On the lateral side, the entry portal is on the sloping face of the lateral condyle, just distal and lateral to Gerdy's tubercle.

The holes are then enlarged and directed distally with a curved awl. Nail size is determined with the aid of the image intensifier by placing a trial nail along the subcutaneous border of the tibia with the fracture reduced or pulled out to length. The proximal eyelet of the nail should lie just proximal to the entry portal and the tip of the nail should reach the old epiphyseal scar, 1-2 cm proximal to the ankle joint. The fracture configuration and its location determine the number and size of the nails to be used. Nail length varied from 30 to $36 \mathrm{~cm}$ and diameters varied from 3.0 to $4.0 \mathrm{~mm}$. Different combination of diameters were used. Number of nails used varied from 2-3 and two nails were most commonly used. The convexity of one or two nails was directed towards the side of maximum comminution in order to neutralise or minimize bending stresses at the fracture site. Few of our initial cases with fractures of lower third of tibia had valgus deformity at ankle, so we subsequently added fibular plating in these cases. All cases were initially immobilized in above the knee posterior splint and kept elevated; partial weight bearing was allowed between 3-4 weeks. In open fractures, weight bearing was allowed only after soft tissue healing and some radiographic evidence of callus.

\section{Above Knee Cast}

The treatment method was based on the type of fractures and the amount of displacement and amount of soft tissue injury. Minimally displaced fractures were reduced by traction and compression methods followed by cast application were treated with an above knee cast with the knee in $10^{\circ}$ of flexion. Patients who presented with extensively comminuted fractures, patients who were not fit for surgery are treated by above knee slab and followed by cast application. ${ }^{8}$ 
Patients with closed fractures requiring manipulation were reduced under regional Anaesthesia and a long-leg cast applied. Those not requiring manipulation had the long leg cast applied under sedation. Care was taken to place the ankle in neutral position. At 6 weeks an X-ray was repeated and if showed signs of union the cast were removed and PTB were applied and patients were advised partial weight bearing. At 3 months, a repeat X-ray was done and based on clinical and radiological evidence of union, partial weight bearing was allowed and gradually to full weight bearing.

We report the results of flexible, intramedullary Ender nailing for 18 diaphyseal fractures of tibia of which 15 closed, 3 Grade I open with a followup ranging from 6 to 24 months. The technique of Ender nail instrumentation combines the benefits of both surgical and closed functional methods of treatment.

\section{Followup}

The patients were followed up every four weeks for first four visits and thereafter every three months for a minimum period of six months. At each follow-up, patient was assessed both clinically and radiologically. The results obtained were statistically analysed, range and the means were calculated.

\section{RESULTS}

\section{Statistical Methods Employed}

Following statistical methods were employed in the present study.

- Contingency Coefficient analysis (CC).

- Chi-Square test.

- One-Way ANOVA.

This study group comprises of 60 patients, of whom 40 patients were treated by surgical means and 20 patients by conservative methods. In the surgical group, 18 patients were treated by CRIF with Ender nailing and 22 patients with CRIF with IMIL nail. These patients were followed up for an average period of 12 months.

About $36.7 \%$ of the patients were between $18-30$ years, $56.7 \%$ of the patients were $31-50$ years and $6.7 \%$ of the patients were above 50 years of age respectively. The average was 40 years (Table 1, Graph 1). This study had male preponderance of $78.3 \%$ (Table 2, Graph 2).

In this study, $81.7 \%$ of the patients sustained closed type of injury and $18.3 \%$ were Grade 1 open type (Table 3, Graph $3)$. Keneth $D^{6}$ reported the type injury to $75 \%$ of closed and $25 \%$ of Grade- 1 open type.

There were 4 groups based on mechanism of injury, $65.0 \%$ of the causes were due to the road traffic accidents, $15 \%$ due to fall from a levelled surface to left side, $10 \%$ to right side and rest $10 \%$ due to fall from a height (Table 4, Graph 4). James J. Hutson ${ }^{9}$ reported most common cause was by RTA, that is $54 \%$ of the cases.

In this study $38.3 \%$ of the patients were oblique type of fracture, $28.3 \%$ were transverse type, $21.7 \%$ were comminuted type, $6.7 \%$ were segmental and $5 \%$ were spiral type. There is significant association with type of fracture frequency with maximum being oblique type (Table 5, Graph 5).

The average time of interval for clinical union of fracture was 12.4 weeks with a standard deviation of 1.76 in case of fracture treatment with CRIF with EN and 12.18 weeks with a standard deviation of 1.74 in case of fracture treatment with
CRIF with IMIL, and 14.8 weeks with a standard deviation of 3.07 in case fracture treatment with $\mathrm{AK}$ cast (Table 6, Graph 6).

The average time interval for radiological union of fracture was 16.11 weeks with a standard deviation of 1.87 in case of fracture treatment with CRIF with EN and 15.9 weeks with a standard deviation of 2.58 in case of fracture treatment with CRIF with IMIL and 18.8 weeks with a standard deviation of 2.86 in case of fracture treatment with AK cast. (Table 6, Graph 6).

In IMIL method out of 22 patients, 17 patients had satisfactory results, 3 patients had Fair and 2 had poor results. Paul and Sander study showed 50\% excellent, 29\% good, 5\% fair and $16 \%$ poor results.

One of the common complications encountered in surgical group of patients was infection, superficial infection is $11.1 \%$ and deep infection is $16.7 \%$ in Ender nailing. The incidence reported by Kessler ${ }^{10}$ was $7.2 \%$ for surgical infection.

This study showed $9.1 \%$ deep infection, $4.5 \%$ delayed union, $4.5 \%$ ankle stiffness, $13.6 \%$ knee stiffness, $13.6 \%$ pin tract infection in IMIL procedure (Table 7, Graph 7) and 18.2\% had $5^{0}$ posterior angulation. Paul and Sander ${ }^{5}$ noted in their series, $4 \%$ deep infection and $18 \%$ delayed union.

The average time of radiological union was 16.1 weeks for Ender nailing (Table 6, Graph 6). David $\mathrm{C}$ et al ${ }^{11}$ in a prospective study obtained union time of 18 weeks.

The results of functional evaluation of the tibia treated by surgical means showed $64.4 \%$ good-to-excellent results; 16.7\% Fair and 33.3\% Poor for Ender nailing (Table 8, Graph 8). Antii ${ }^{12}$ reported $80 \%$ of the patients had good-to-excellent result, $12 \%$ fair and $8 \%$ poor for Ender nailing.

This study showed knee stiffness in $13.6 \%$ of the patients managed surgically, $10 \%$ of the patients had ankle stiffness and $22.2 \%$ had a deformity of $5^{0}$ posterior angulation at the fracture site (Table 9).

The average time of radiological union was 15.9 weeks for IMIL nailing. Wiss DA 7 fracture union was average 18 weeks.

The results of functional evaluation of 20 patients treated by conservative treatment methods showed $30 \%$ excellent, $50 \%$ good, $10 \%$ fair and $10 \%$ poor results. These results were comparable to the study done by David C, where they got goodto-excellent results in $62 \%$ of the patients. The radiological union of fracture in our study was 18.8 weeks, Sarmiento ${ }^{13}$ in his study showed 17.8 weeks union. This study shows $10 \%$ of delayed union, $20 \%$ of ankle stiffness, $25 \%$ of knee stiffness and $25 \%$ of $5^{0}$ varus deformity and $10 \%$ of $6 \mathrm{~mm}$ shortening. Sarmiento ${ }^{14}$ and Latta ${ }^{15}$ showed $14 \%$ of delayed union, $18 \%$ ankle stiffness, $30 \%$ of knee stiffness.

\section{Age Incidence}

\begin{tabular}{|c|c|c|c|}
\hline Age in Years & Enders Nail & IMIL Nail & Cast \\
\hline $18-30$ & 8 & 8 & 6 \\
\hline $31-50$ & 9 & 13 & 12 \\
\hline$>50$ & 1 & 1 & 2 \\
\hline \multicolumn{2}{|r}{ Table 1: Frequency of Treatment with Age } \\
\hline
\end{tabular}




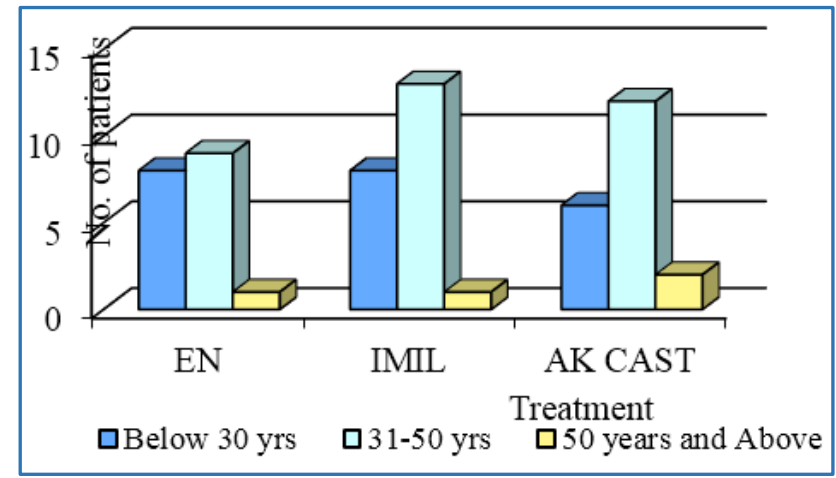

Graph 1: Treatment with Age Groups

Type of Injury 9

\begin{tabular}{|c|c|c|}
\hline Valid & Frequency & Percent \\
\hline C & 49 & 81.7 \\
\hline Gr-1 & 11 & 18.3 \\
\hline Total & $\mathbf{6 0}$ & $\mathbf{1 0 0 . 0}$ \\
\hline \multicolumn{3}{|c|}{ Table 2: Frequency of Type of Injury } \\
\hline
\end{tabular}

$\chi^{2}=24.067 ; \mathrm{p}<0.000$ (HS).

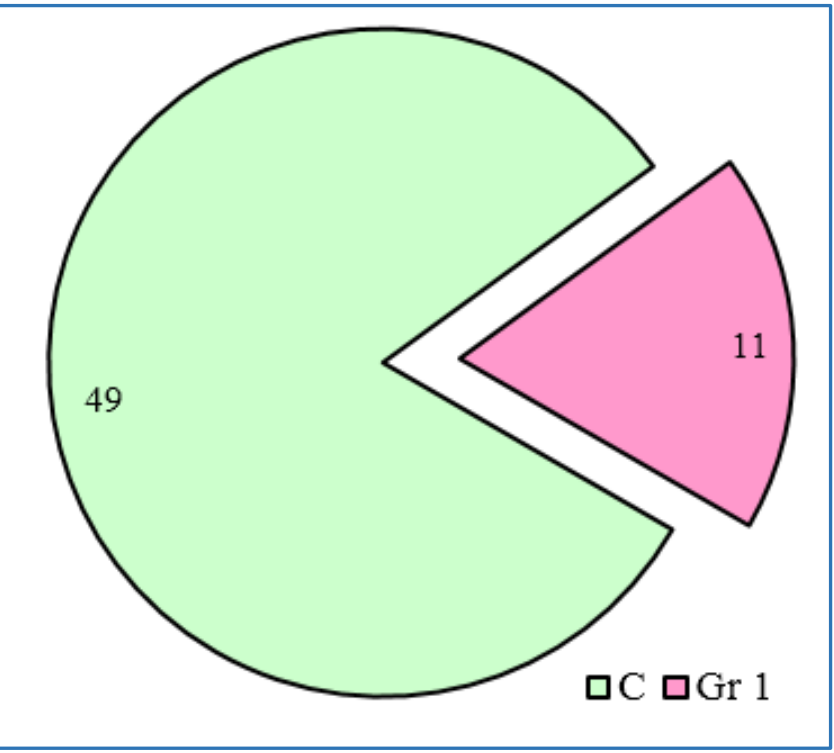

Graph 2: Type of Injury

Mechanism of Injury

\begin{tabular}{|c|c|c|c|c|}
\hline \multirow{2}{*}{ Mode of Injury } & \multicolumn{2}{|c|}{ Sex } & \multirow{2}{*}{ Total } \\
\cline { 2 - 5 } & Male & Female & \\
\hline \multirow{2}{*}{ RTA } & Count & 31 & 8 & 39 \\
\cline { 2 - 5 } & Percentage & 66.0 & 61.5 & 65.0 \\
\hline \multirow{2}{*}{ Fall $\{\mathrm{L}\}$} & Count & 5 & 4 & 9 \\
\cline { 2 - 5 } & Percentage & 10.6 & 30.8 & 15.0 \\
\hline \multirow{2}{*}{ Fall $\{\mathrm{R}\}$} & Count & 5 & 1 & 6 \\
\cline { 2 - 5 } & Percentage & 10.6 & 7.7 & 10.0 \\
\hline \multirow{2}{*}{ Fall $\{\mathrm{H}\}$} & Count & 6 & - & 6 \\
\cline { 2 - 5 } & Percentage & 12.8 & - & 10.0 \\
\hline \multirow{4}{*}{} & Count & 47 & 13 & 60 \\
\cline { 2 - 5 } & Percentage & 100.0 & 100.0 & 100.0 \\
\hline \multicolumn{3}{|c|}{ Table 3: Mode of Injury with Sex ${ }^{\mathbf{1 6}}$} \\
\hline
\end{tabular}

$\mathrm{CC}=0.265 ; \mathrm{P}<0.210(\mathrm{NS})$.

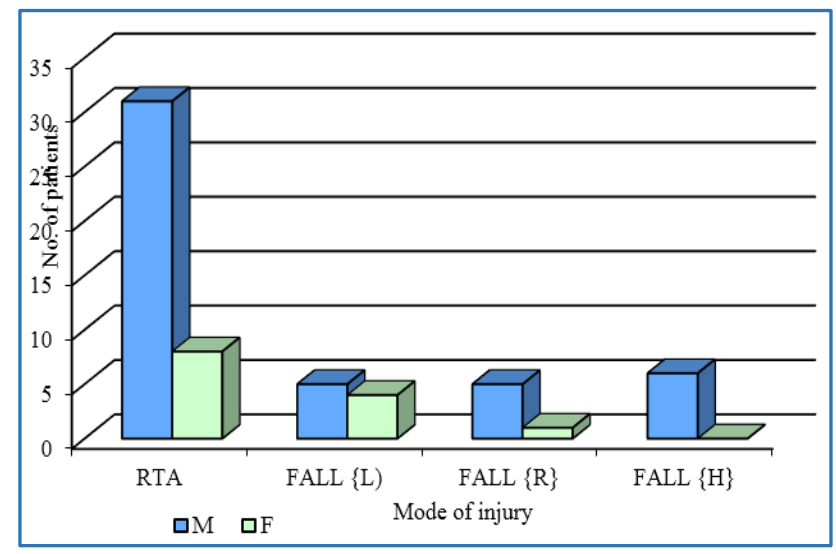

Graph 3: Mechanism of Injury

Type of Fracture17

\begin{tabular}{|c|c|c|}
\hline Type of Fracture & Frequency & Percent \\
\hline OBLIQUE & 23 & 38.3 \\
\hline TRANS & 17 & 28.3 \\
\hline COMMI & 13 & 21.7 \\
\hline SEGM & 4 & 6.7 \\
\hline SPIRAL & 3 & 5.0 \\
\hline Total & $\mathbf{6 0}$ & $\mathbf{1 0 0 . 0}$ \\
\hline \multicolumn{2}{|c|}{ Table 4: Frequency of Type of Fracture } \\
\hline
\end{tabular}

$\chi^{2}=24.33 ; \mathrm{p}<0.000$ (HS).

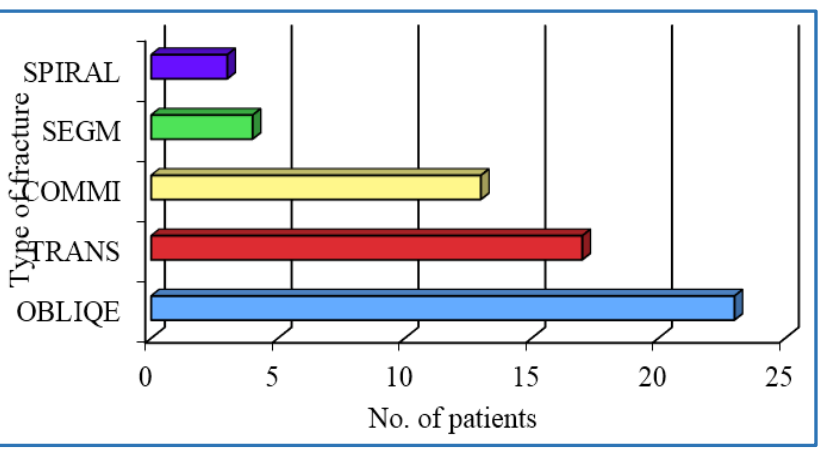

Graph 4: Type of Fracture

Average Time of Fracture Union 18

\begin{tabular}{|c|c|c|c|c|c|c|}
\hline & & $\mathbf{N}$ & Mean & Std. Deviation & $\mathbf{F}$ & $\mathbf{P}$ \\
\hline \multirow{4}{*}{ 苞 } & EN & 18 & 12.4444 & 1.7564 & \multirow{4}{*}{8.119} & \multirow{4}{*}{0.001} \\
\hline & IMIL & 22 & 12.1818 & 1.7358 & & \\
\hline & AK Cast & 20 & 14.8000 & 3.0711 & & \\
\hline & Total & 60 & 13.1333 & 2.5343 & & \\
\hline \multirow{4}{*}{ 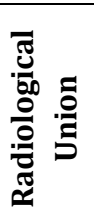 } & EN & 18 & 16.1111 & 1.8752 & \multirow{4}{*}{7.895} & \multirow{4}{*}{0.001} \\
\hline & IMIL & 22 & 15.9091 & 2.5803 & & \\
\hline & AK CAST & 20 & 18.8000 & 3.0711 & & \\
\hline & Total & 60 & 16.9333 & 2.8634 & & \\
\hline \multicolumn{7}{|c|}{$\begin{array}{c}\text { Table 5: Average Time of Fracture } \\
\text { Union with Treatment }\end{array}$} \\
\hline
\end{tabular}




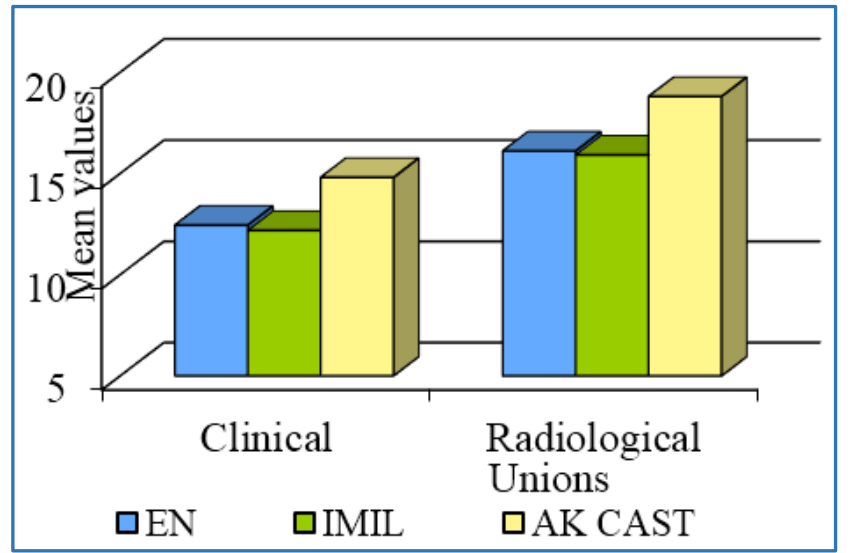

Graph 5: Average Time of Fracture Union

Complication 19

\begin{tabular}{|c|c|c|c|c|c|}
\hline \multirow{2}{*}{\multicolumn{2}{|c|}{ Compilation }} & \multicolumn{3}{|c|}{ Treatment } & \multirow{3}{*}{$\begin{array}{c}\text { Total } \\
32\end{array}$} \\
\hline & & \multirow{2}{*}{$\begin{array}{l}\text { EN } \\
11\end{array}$} & \multirow{2}{*}{$\begin{array}{c}\text { IMIL } \\
12\end{array}$} & \multirow{2}{*}{$\begin{array}{c}\begin{array}{c}\text { AK } \\
\text { CAST }\end{array} \\
9\end{array}$} & \\
\hline \multirow{2}{*}{ Nil } & Frequency & & & & \\
\hline & Percentage & $61.1 \%$ & $54.5 \%$ & $45.0 \%$ & $53.3 \%$ \\
\hline \multirow{2}{*}{$\begin{array}{c}\text { Sup } \\
\text { Infection }\end{array}$} & Frequency & 2 & - & - & 2 \\
\hline & Percentage & $11.1 \%$ & - & - & $3.3 \%$ \\
\hline \multirow{2}{*}{$\begin{array}{c}\text { Deep } \\
\text { Infection }\end{array}$} & Frequency & 3 & 2 & - & 5 \\
\hline & Percentage & $16.7 \%$ & $9.1 \%$ & - & $8.3 \%$ \\
\hline \multirow{2}{*}{$\begin{array}{c}\text { Delayed } \\
\text { Union }\end{array}$} & Frequency & - & 1 & 2 & 3 \\
\hline & Percentage & - & $4.5 \%$ & $10.0 \%$ & $5.0 \%$ \\
\hline \multirow{2}{*}{$\begin{array}{c}\text { Ankle } \\
\text { Stiffness }\end{array}$} & Frequency & 1 & 1 & 4 & 6 \\
\hline & Percentage & $5.6 \%$ & $4.5 \%$ & $20.0 \%$ & $10.0 \%$ \\
\hline \multirow{2}{*}{$\begin{array}{c}\text { Knee } \\
\text { Stiffness }\end{array}$} & Frequency & - & 3 & 5 & 8 \\
\hline & Percentage & - & $13.6 \%$ & $25.0 \%$ & $13.3 \%$ \\
\hline \multirow{2}{*}{$\begin{array}{l}\text { Pin Tract } \\
\text { Infection }\end{array}$} & Frequency & 1 & 3 & - & 4 \\
\hline & Percentage & $5.6 \%$ & $13.6 \%$ & - & $6.7 \%$ \\
\hline \multirow{2}{*}{ Total } & Frequency & 18 & 22 & 20 & 60 \\
\hline & Percentage & $00.0^{\circ}$ & $100.0 \%$ & $100.0^{\circ}$ & $00.0 \%$ \\
\hline \multicolumn{6}{|c|}{ able 6: Compilation with Treatment } \\
\hline
\end{tabular}

$\mathrm{CC}=0.506 ; \mathrm{P}<0.056(\mathrm{NS})$

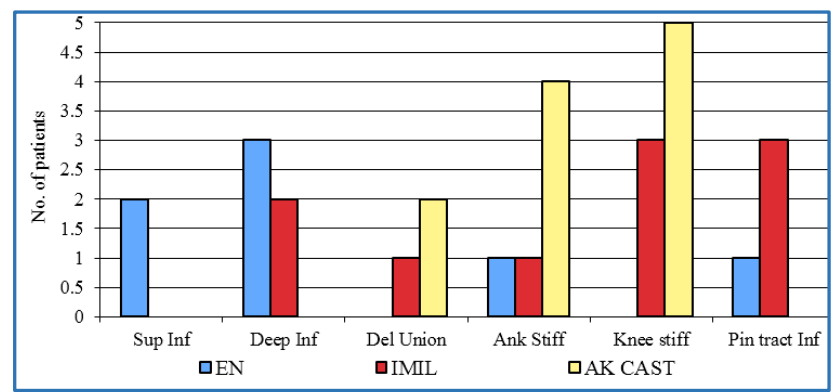

Graph 6: Compilation with Treatment

Results of Treatment

\begin{tabular}{|c|c|c|c|c|c|}
\hline \multirow{2}{*}{ Treatment } & \multicolumn{4}{|c|}{ Results } & \multirow{2}{*}{ Total } \\
\hline & Excellent & Good & Fair & Poor & \\
\hline \multirow{2}{*}{ EN } & 8 & 7 & 1 & 2 & 18 \\
\hline & $32.0 \%$ & $30.4 \%$ & $16.7 \%$ & $33.3 \%$ & $30.0 \%$ \\
\hline \multirow{2}{*}{ IMIL } & 11 & 6 & 3 & 2 & 22 \\
\hline & $44.0 \%$ & $26.1 \%$ & $50.0 \%$ & $33.3 \%$ & $36.7 \%$ \\
\hline \multirow{2}{*}{ AK Cast } & 6 & 10 & 2 & 2 & 20 \\
\hline & $24.0 \%$ & $43.5 \%$ & $33.3 \%$ & $33.3 \%$ & $33.3 \%$ \\
\hline \multirow{2}{*}{ Total } & 25 & 23 & 6 & 6 & 60 \\
\hline & $100.0 \%$ & $100.0 \%$ & $100.0 \%$ & $100.0 \%$ & $100.0 \%$ \\
\hline \multicolumn{6}{|c|}{ Table 7: Results with Treatment } \\
\hline
\end{tabular}

$\mathrm{CC}=0.223 ; \mathrm{P}<0.789$ (NS)

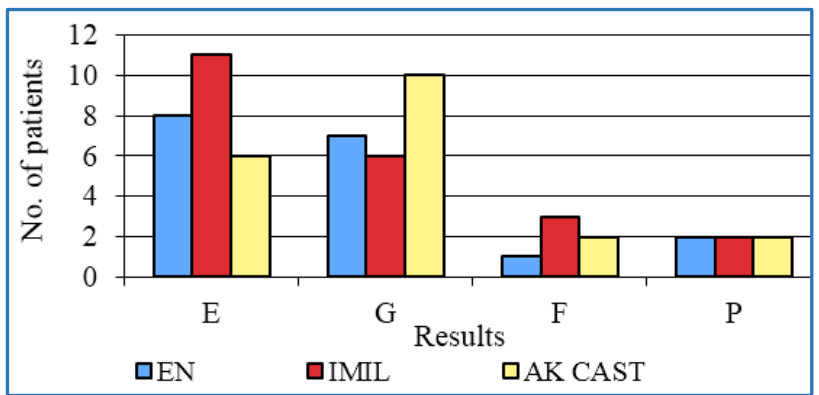

Graph 7: Results of Treatment

Deformity at Fracture Site ${ }^{12}$

\begin{tabular}{|c|c|c|c|c|}
\hline \multirow{2}{*}{ Deformity } & \multicolumn{3}{|c|}{ Treatment } & \multirow{2}{*}{ Total } \\
\hline & EN & IMIL & AK Cast & \\
\hline \multirow{2}{*}{ Nil } & 7 & 12 & 4 & 23 \\
\hline & $38.9 \%$ & $54.5 \%$ & $20.0 \%$ & $38.3 \%$ \\
\hline \multirow{2}{*}{$5^{0}$ valgus } & 2 & - & 2 & 4 \\
\hline & $11.1 \%$ & - & $10.0 \%$ & $6.7 \%$ \\
\hline \multirow{2}{*}{$5^{0}$ varus } & 1 & - & 5 & 6 \\
\hline & $5.6 \%$ & - & $25.0 \%$ & $10.0 \%$ \\
\hline \multirow{2}{*}{$5^{0}$ post ang } & 1 & 4 & 1 & 6 \\
\hline & $5.6 \%$ & $18.2 \%$ & $5.0 \%$ & $10.0 \%$ \\
\hline \multirow{2}{*}{$10^{0}$ post ang } & 1 & - & 2 & 3 \\
\hline & $5.6 \%$ & - & $10.0 \%$ & $5.0 \%$ \\
\hline \multirow{2}{*}{$5^{0}$ ant ang } & - & 1 & 2 & 3 \\
\hline & - & $4.5 \%$ & $10.0 \%$ & $5.0 \%$ \\
\hline \multirow{2}{*}{$\begin{array}{c}5^{0} \text { post ang/ } \\
3 \mathrm{~cm} \text { short }\end{array}$} & 4 & 3 & 2 & 9 \\
\hline & $22.2 \%$ & $13.6 \%$ & $10.0 \%$ & $15.0 \%$ \\
\hline \multirow{2}{*}{$\begin{array}{l}70 \text { valgus/ } \\
3 \mathrm{~cm} \text { short }\end{array}$} & 1 & 2 & - & 3 \\
\hline & $5.6 \%$ & $9.1 \%$ & - & $5.0 \%$ \\
\hline \multirow{2}{*}{$\begin{array}{l}4^{0} \text { ant ang/ } \\
2 \mathrm{~cm} \text { short }\end{array}$} & 1 & - & - & 1 \\
\hline & $5.6 \%$ & - & - & $1.7 \%$ \\
\hline \multirow[t]{2}{*}{$6 \mathrm{~mm}$ short } & - & - & 2 & 2 \\
\hline & - & - & $10.0 \%$ & $3.3 \%$ \\
\hline \multirow{2}{*}{ Total } & 18 & 22 & 20 & 60 \\
\hline & $100.0 \%$ & $100.0 \%$ & $100.0 \%$ & $100.0 \%$ \\
\hline \multicolumn{5}{|c|}{ Table 8: Deformity at Fracture Site with Treatment } \\
\hline
\end{tabular}

Case No. 1:

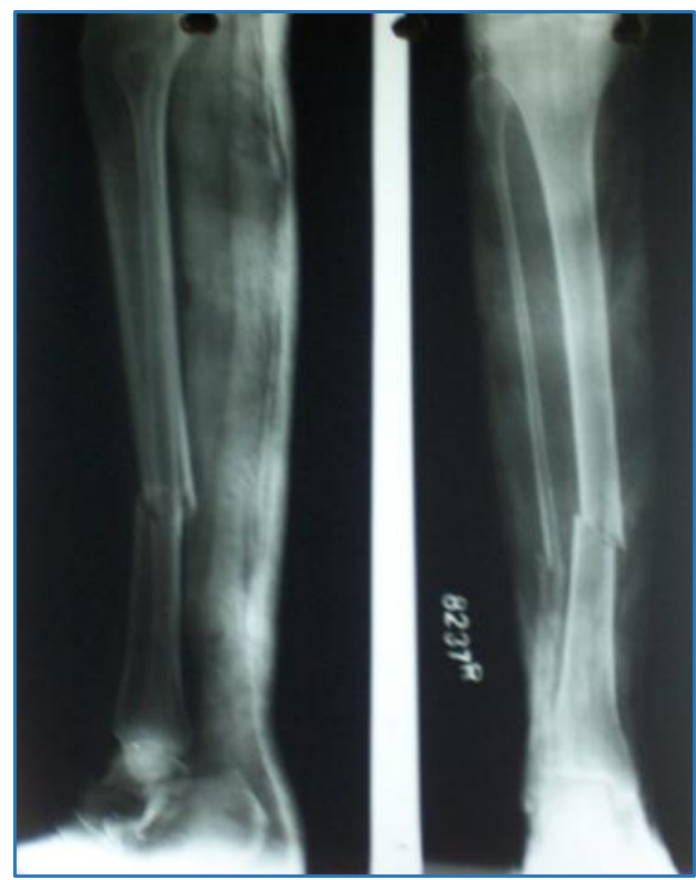

Fig. 1: Pre-Operative X-Ray 


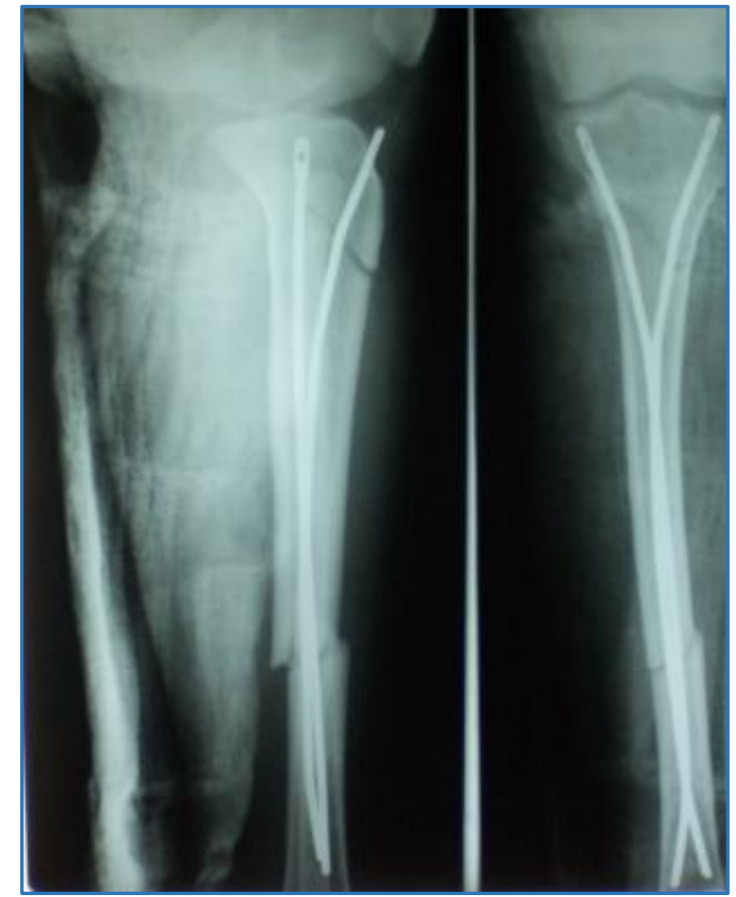

Fig. 2: Immediate Post-Operative X-Ray

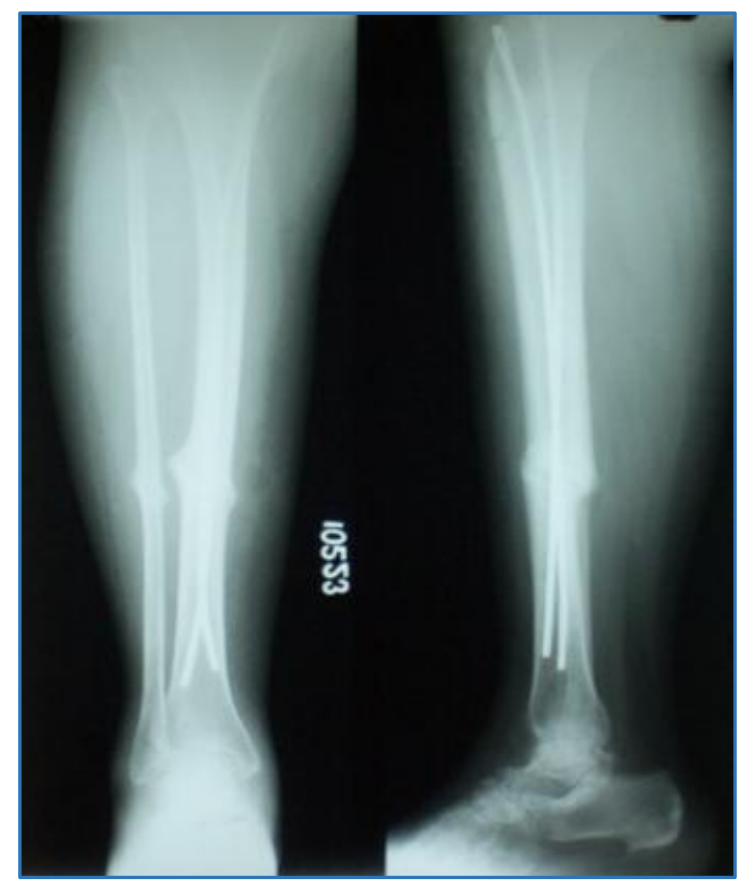

Fig. 3: Callus Formation at $16^{\text {th }}$ Week

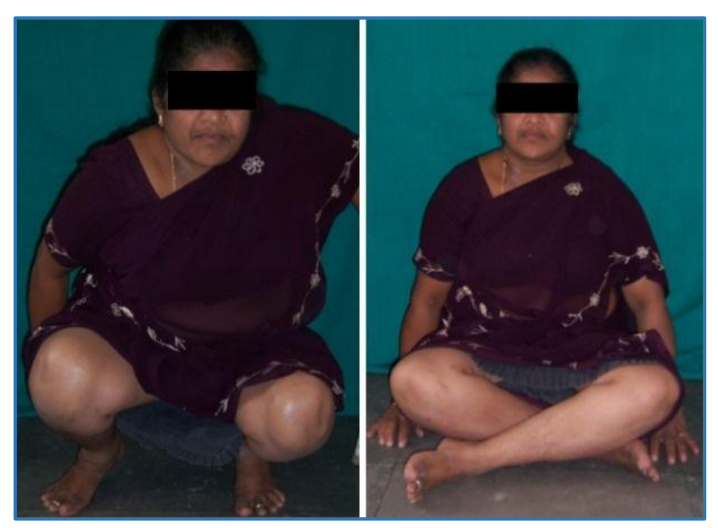

Fig. 4: Squatting and Sitting Cross-Legged
Case No. 2:

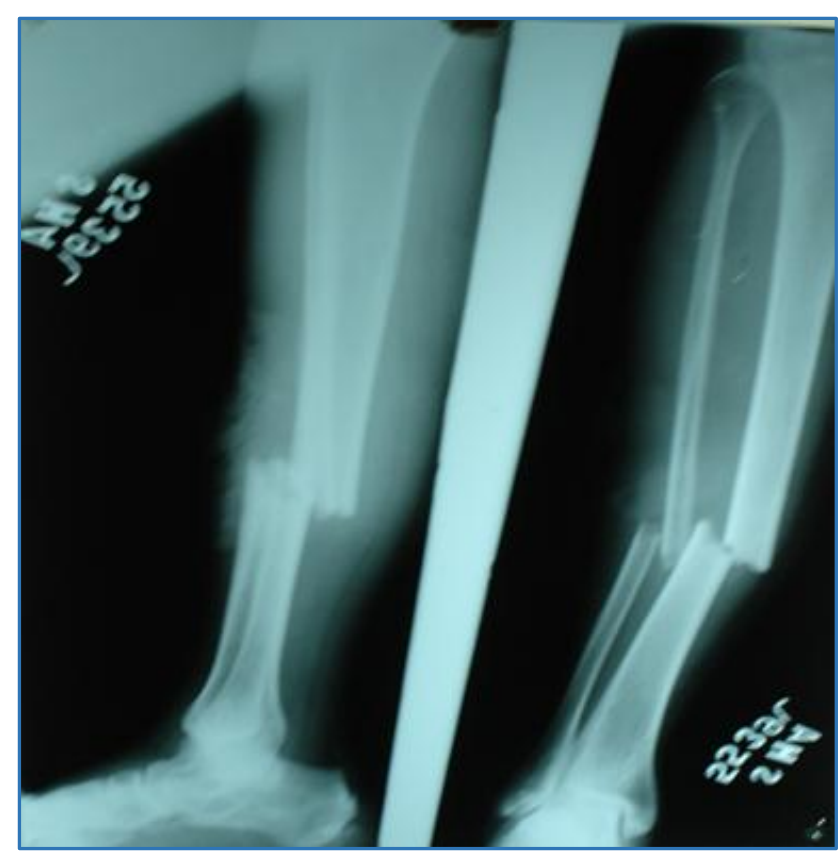

Fig. 5: Pre-Operative X-Ray

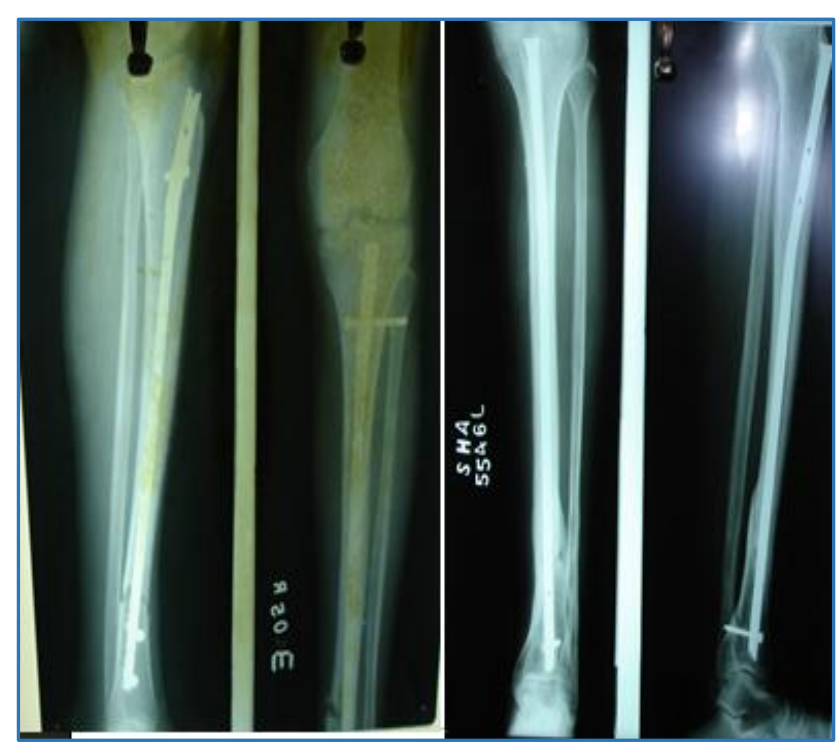

Fig. 6: Post-Operative X-Ray with IMIL Nail in Situ

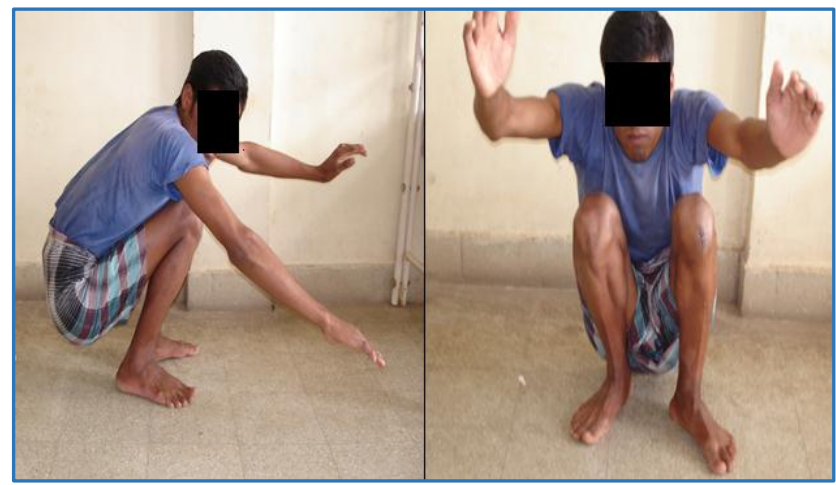

Fig. 7: Range of Movements 16 Weeks Squatting (Front and Side View) 
Case No. 3:

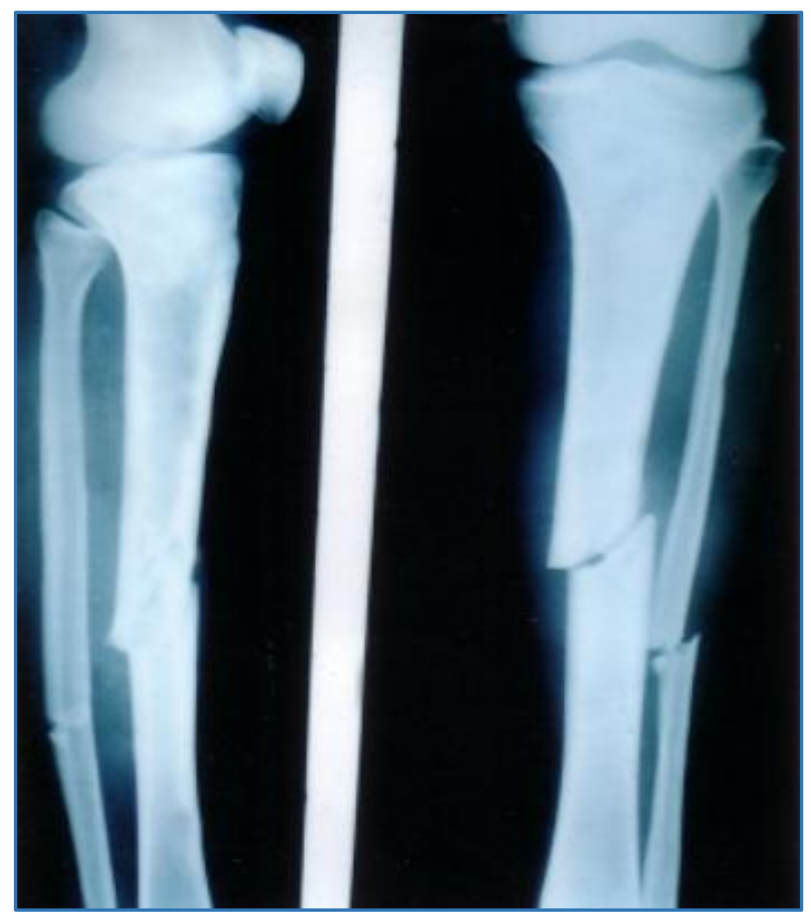

Fig. 8: Comminuted Fracture of Middle 1/3rd Tibia

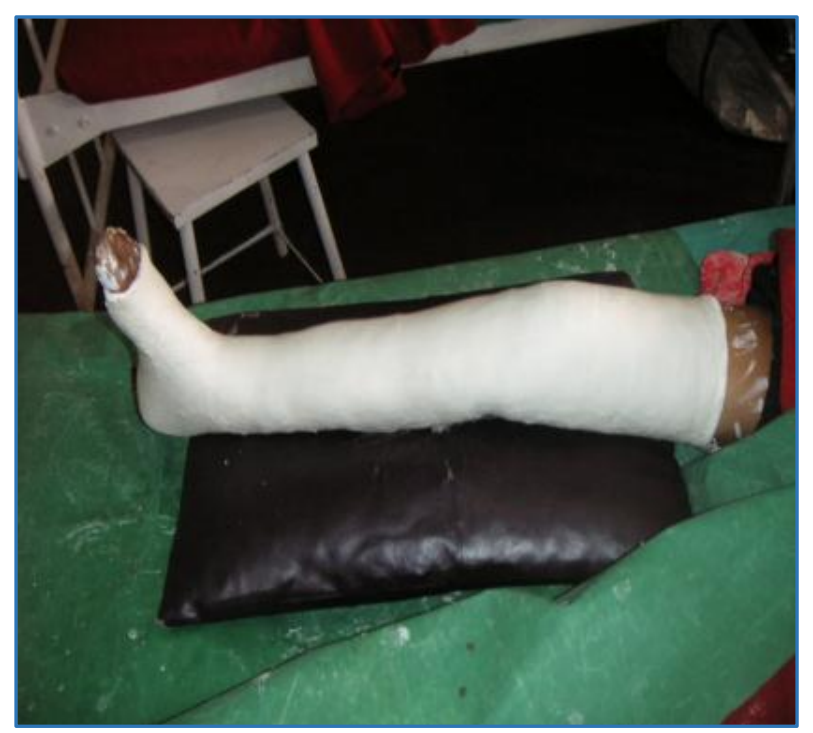

Fig. 9: Reduced and Above Knee Cast Applied

\section{DISCUSSION}

The management of fracture of the tibial shaft continues to be common orthopaedic problem and significant difference of opinion persists regarding the modalities of treatment.

During the past few years, there has been a renewed interest in intramedullary nailing of tibial shift fractures. However, there is no consensus of opinion regarding the timing of operation, the type of nail to be used or the necessity to ream. The degree of stability following intramedullary nailing depends upon the length and the shape of the fracture configuration and the technique of nailing itself.

In modern times, Bohler recommended preliminary skeletal traction for 1 to 3 weeks for difficult tibial fractures and long leg cast treatment and approach that yielded satisfactory results.
Watson-Jones advocated long leg cast treatment for several months or until the fracture had healed. His rate of non-union was very low, but it was not reported in detail. For example, he did not mention the effect of prolonged cast immobilization on joint motion and muscle atrophy.

Early in his career, Charnley ${ }^{1}$ produced his classic text closed reduction of common fractures (1961), he meticulously described in detail how to reduce tibia-fibula fractures (Making use of the periosteal sleeve) and outlined the limitations of the technique described. He recognized a problem reported recently by others, namely the problem of the intact fibula which allows the tibia to drift into varus and increases the incidence of delayed union.

The conservative school of treatment flourished for almost three decades until the early 1960s, when the Swiss Arbeitsgemeinschaft fur Osteosynthesefragen (AO) group advocated open reduction and internal fixation with plating as a primary treatment of both closed and open tibia fractures. Their rationale was that prolonged cast immobilization lead to poor results. Numerous publications in the early 1970s supported the AO approach and documented early recovery and good functional result. In this approach, however, the incidence of sepsis and non-union increases considerably, particularly in the primary plating of open fractures.

In 1968, Kuntscher proposed a new device called Detensor nail for comminuted fractures. This principle of 'Detensor effect' of achieving stability with transverse bolts through prefabricated holes in the nail has become the basis of the interlocking nail.

In 1995, J. Dean Cole et $\mathrm{al}^{2}$ proposed that immediate postdebridement wound coverage and intramedullary nailing after reconstruction of soft tissue envelope facilitate fracture healing in these complex open injuries. I.M. nailing can be performed safely to include all grades of open tibial fractures from the proximal or distal metaphysis.

In 1995, Gregony M. Gorngiadis, ${ }^{3}$ proposed that acute tibial shaft fractures complicated by a compartment syndrome were treated with immediate decompressive fasciotomies, bony stabilization with a locked unreamed I.M. nail and early active joint motion. This treatment protocol simplifies the bony and soft tissue management in patients with this combination of injuries.

In 1997, Lawrence B. Bone et $\mathrm{al}^{4}$ concluded that the treatment of displaced closed fractures of tibial shaft with closed I.M. nailing provides functional results that are superior to those obtained with use of a cost.

In 1998, Frederic W. Rhinelander, ${ }^{20}$ concluded the results in medullary fixation experiments suggest that the best configuration for an I.M. nailing is one with open spaces on flutes extending longitudinally between flanges. The flanges coil give firm support to all sectors of endosteal cortex and the flutes will permit regeneration of the essentially medullary angulation as rapidly as possible.

Court Brown C.M., ${ }^{21}$ in 1996 had done prospective randomized study on 50 patients with Tscherne C1 tibial diaphyseal fractures comparing treatment with reamed and unreamed intramedullary nails. Our result shows that reamed nailing is associated with a significantly lower time to union and a reduced requirement for a further operation. Unreamed nailing should not be used in the treatment of common Tscherne C1 tibial fracture. 
A. Paige Whittle,22 in 1992 had studied fifty open fractures of the tibial shaft that were treated with debridement and interlocking nailing without reaming were followed for an average of twelve months. Most of the fractures were the result of high-energy trauma and 68 percent of the fracture wounds were grade III. Forty-eight ( 96 percent) of the fifty fractures united at an average of seven months; there were no mal-unions. There were four infections ( 8 percent), all at the sites of Grade III fractures. These results are comparable with or better than those obtained with other forms of fixations including immobilization with a cast, unlocked intramedullary nailing and external fixation.

A Dardu Garcia,23 in 1998 had done thirty-nine open unstable tibial shaft fractures treated with a non-reamed flexible, locked intramedullary nail. There were 23 Grade I, 12 Grade II, 3 Grade IIIA, and 1 Grade IIIB fractures. The average time of follow-up assessment was 24 months. There were no implant failures. It was concluded that non-reamed flexible locked nailing provides effective control of axial and rotational stability in unstable Grade I to IIIA open fractures with acceptable union rates and low incidence of complications secondary to the fixation system.

Donald A. Wiss, ${ }^{7}$ in November 1986 in a non-randomized prospective study, 111 tibial shaft fractures (55 closed, 56 open) were treated with flexible intramedullary nails. Ninety four percent of the fractures united in an average time of 18.8 weeks. There were seven non-unions (6.3\%). Flexible medullary nailing extends the indications for intramedullary fixation of tibial shaft fractures because maintenance of length, alignment and rotation are usually possible.

Leland Mayer, M.D.,24 in 1985 had done fifty-one severe fractures of the tibial shaft with multiple intramedullary Ender nails. Thirty-six fractures were treated within two weeks after injury. Forty-one fractures united in less than four months and eight in four to eight months. It has been our experience that Ender nails provide excellent rotational stability, allow early full weight-bearing and markedly decrease the duration of need for immobilization. Ender nailing was of value both for the acute management of complicated high energy fractures of the tibial shaft with extensive soft-tissue damage and as a salvage procedure to maintain reduction of a fracture when other techniques had failed.

John L. Holbrook,25 in 1989 had a randomized, prospective study comparing Ender nailing with external fixation for open fractures of sixty-three tibia was undertaken. Ender nailing is a safe alternative to external fixation for Grade I and Grade II open fractures. It should not be used for comminuted fracture, which might shorten about the nails.

Mayer L, ${ }^{24}$ (1985) reported good results in 36 of 38 fractures with flexible nailing. Ender type curved pins with medial and lateral entry portals for rotational control of the fracture were used. Stacking of multiple pins exert spring force to resist angulation and rotation. They require a stable fracture configuration and fracture of middle one-third are best controlled.

\section{CONCLUSION}

Out of the various treatment modalities, in our experience surgical management of diaphyseal tibial fractures has better functional outcomes compared to conservative management. The incidence of complications like knee and ankle stiffness and malunion are much lesser in surgical management compared to the patients managed conservatively. Out of the two surgical methods, patients operated with IMIL nails had better function and less complications.

\section{REFERENCES}

1. Charnley J. Closed treatment of common fractures. 3rd ed. Edinburgh: Churchill Livinstone 1961.

2. Cole JD, Ansel LJ, Schwartzberg R. A sequential protocol for management of severe open tibial fractures. Clin Orthop Relat Res 1995;315:84-103.

3. Georgiadis GM. Tibial shaft fractures complicated by compartment syndrome: treatment with immediate fasciotomy and locked unreamed nailing. J of Trauma 1995;38(3):448-52.

4. Bone LB, Sucato D, Stegemann PM, et al. Displaced isolated fractures of the tibial shaft treated with either a cast or intramedullary nailing. JBJS Am 1997;79(9):133641.

5. Gregory P, Sanders R. The treatment of closed, unstable tibial shaft fractures with unreamed interlocking nail. Clin Orthop Relat Res 1995;315:48-55.

6. Johnson KD. Indications, instrumentations and experience with locked tibial nails. J Orthop 1985;8(11):1377-83.

7. Wiss DA. Flexible medullary nailing of acute tibial shaft fractures. Clinical Orthopedics and Related Research 1986;212:122-32.

8. Sarmiento A, Sobol PA, Hoy SAL, et al. Prefabricated functional braces for the treatment of the tibial diaphysis fractures. JBJS Am 1984;66(9):1328-39.

9. Hutson JJ, Zych GA, Cole JD, et al. Mechanical failures of intramedullary tibial nails applied without reaming. Clin Orthop Relat Res 1995;315:129-37.

10. Kessler SB, Hallfeldt KK, Perren SM, et al. The effect of reaming and intramedullary nailing of fracture healing.Clin Orthop Relat Res 1986;212:18-25.

11. Templeman DC, Thoams M, Varecka T, et al. Exchange reamed intramedullary nailing for delayed union and non-union of the tibia. Clin Orthop Relat Res 1995;315:169-75.

12. Alho A, Ekeland A, Stromose K, et al. Locked intramedullary nailing for displaced tibial shaft fractures. JBJS Br 1990;72(5):805-9.

13. Sarmiento A, Sharpe FE, Ebramzadeh E, et al. Factors influencing the outcome of closed tibial fractures treated with functional bracing. Clin Orthop Relat Res 1995;315:8-24.

14. Sarmiento A. A functional below the knee cast for tibial fractures. JBJS Am 1967;49(5):855-75.

15. Latta LL, Sarmienth A, Tarr RR. The rationale functional bracing of fractures. Clin Orthop Relat Res 1980;146:2836.

16. Rockwood CA, Green DP, Bucholz RW. Rockwood and Green's fractures in adults. Philadelphia: Lippincott Company 1991:121.

17. Zych GA, Hutson JJ. Diagnosis and management of infection after tibial intramedullary nailing. Clin Orthop Relat Res 1995;315:153-62.

18. Krettek C, Schandelmaier P, Scherne H. Non-reamed interlocking nailing of closed tibial fractures with severe soft tissue injury. Clin Orthop Relat Res 1995;315:34-47. 
19. Wiss DA, Stetson WB. Unstable fractures of the tibia treated with a reamed intramedullary interlocking nail. Clin Orthop Relat Res 1995;315:56-63.

20. Rhinelander FW. Effects of medullary nailing on the normal blood supply of diaphyseal cortex 1973. Clin Orthop Relat Res 1998;350:5-17.

21. Court-Brown CM, Will E, Christie J, et al. Reamed or unreamed nailing for closed tibial fractures: a prospective study in Tscherne C1 fractures. JBJS Am 1996;78(4): 580-3.

22. Whittle AP, Russell TA, Taylor JC, et al. Treatment of open fractures of the tibial shaft with the use of interlocking nailing without reaming. JBJS Am 1992;74(8):1162-71.
23. Darder-Garcia A, Dardar-Prats, Gomar-Sancho F.Nonreamed flexible locked intramedullary nailing in tibial open fractures. Clinical Orthopaedics and Related Research 1998;350:97-104.

24. Mayer L, Werbie T, Schwab JP, et al. The use of Ender nails in fracture of the tibia shaft. JBJS Am 1985;67(3):446-55.

25. Holbrook JL, Swiontkowski MF, Sanders R. Treatment of open fracture of the tibial shaft: ender nailing versus external fixations. JBJS Am 1989;71(8):1231-8. 